University of Nebraska - Lincoln

DigitalCommons@University of Nebraska - Lincoln

USDA Wildlife Services - Staff Publications

U.S. Department of Agriculture: Animal and Plant Health Inspection Service

2014

\title{
Evaluation of Techniques to Reduce Deer and Elk Damage to Agricultural Crops
}

\author{
Heather E. Johnson \\ Colorado Parks and Wildlife, heatherjohnson@usgs.gov \\ Justin W. Fischer \\ USDA/APHIS/WS National Wildlife Research Center, Justin.w.fischer@aphis.usda.gov \\ Matthew Hammond \\ Colorado Parks and Wildlife \\ Patricia D. Dorsey \\ Colorado Parks and Wildlife
}

W. David Walter

United States Department of Agriculture

See next page for additional authors

Follow this and additional works at: https://digitalcommons.unl.edu/icwdm_usdanwrc

Part of the Life Sciences Commons

Johnson, Heather E.; Fischer, Justin W.; Hammond, Matthew; Dorsey, Patricia D.; Walter, W. David; Anderson, Charles; and VerCauteren, Kurt C., "Evaluation of Techniques to Reduce Deer and Elk Damage to Agricultural Crops" (2014). USDA Wildlife Services - Staff Publications. 1507.

https://digitalcommons.unl.edu/icwdm_usdanwrc/1507

This Article is brought to you for free and open access by the U.S. Department of Agriculture: Animal and Plant Health Inspection Service at DigitalCommons@University of Nebraska - Lincoln. It has been accepted for inclusion in USDA Wildlife Services - Staff Publications by an authorized administrator of DigitalCommons@University of Nebraska - Lincoln. 
Authors

Heather E. Johnson, Justin W. Fischer, Matthew Hammond, Patricia D. Dorsey, W. David Walter, Charles Anderson, and Kurt C. VerCauteren 
Original Article

\title{
Evaluation of Techniques to Reduce Deer and Elk Damage to Agricultural Crops
}

\author{
HEATHER E. JOHNSON, ${ }^{\mathbf{1}}$ Colorado Parks and Wildlife, 415 Turner Drive, Durango, CO 81303, USA \\ JUSTIN W. FISCHER, United States Department of Agriculture, Animal and Plant Health Inspection Service, Wildlife Services, \\ National Wildlife Research Center, 4101 LaPorte Avenue, Fort Collins, CO 80521, USA \\ MATTHEW HAMMOND, Colorado Parks and Wildife, 151 E 16th Street, Durango, CO 81301, USA \\ PATRICIA D. DORSEY, Colorado Parks and Wildlife, 415 Turner Drive, Durango, CO 81303, USA \\ W. DAVID WALTER, ${ }^{2}$ United States Department of Agriculture, Animal and Plant Health Inspection Service, Wildlife Services, \\ National Wildlife Research Center, 4101 LaPorte Avenue, Fort Collins, CO 80521, USA \\ CHARLES ANDERSON, ${ }^{3}$ United States Department of Agriculture, Animal and Plant Health Inspection Service, Wildife Services, \\ National Wildlife Research Center, 4101 LaPorte Avenue, Fort Collins, CO 80521, USA \\ KURT C. VerCAUTEREN, United States Department of Agriculture, Animal and Plant Health Inspection Service, Wildlife Services, \\ National Wildlife Research Center, 4101 LaPorte Avenue, Fort Collins, CO 80521, USA
}

\begin{abstract}
Mule deer (Odocoileus hemionus) and Rocky Mountain elk (Cervus elaphus nelsoni) provide important recreational, ecological, and economic benefits, but can also cause substantial damage to agricultural crops. Cervid damage to agriculture creates challenges for wildlife agencies responsible for minimizing crop depredation while maintaining healthy deer and elk populations. Sunflower producers in southwestern Colorado, USA, have experienced high deer and elk damage and were interested in temporary methods to reduce damage that were cost-effective for rotational crops. To address this challenge, we investigated 3 temporary, non-lethal exclusion and repellent techniques for reducing deer and elk damage to sunflowers: 1) a polyrope electric fence, 2) the chemical repellent Plantskydd ${ }^{\mathrm{TM}}$, and 3) a winged fence. During July through October 2011 and 2012, we used a randomized block design to test the efficacy of these techniques by quantifying cervid damage to sunflowers and the number of deer and elk tracks traversing treatment and control plot boundaries. Using generalized linear mixed models we found that polyrope electric fences reduced deer and elk damage and presence within plots, while the repellent and winged fences did not reduce ungulate activity. Polyrope electric fences may be a suitable tool in areas where wildlife management agencies want to maintain deer and elk populations but reduce seasonal damage by cervids to high-value crops. In Colorado, use of an effective exclusion technique such as polyrope electric fence could also decrease the need for lethal depredation permits and damage compensation payments, and increase satisfaction among producers and the public. Published 2014. This article is a U.S. Government work and is in the public domain in the USA.
\end{abstract}

KEY WORDS Cervus elaphus nelsoni, crop damage, electric fence, elk, mule deer, Odocoileus hemionus, repellent, sunflowers, wildlife damage management, winged fence.

Mule deer (Odocoileus hemionus) and Rocky Mountain elk (Cervus elaphus nelsoni) provide important recreational, ecological, and economic benefits, but they also can cause substantial damage to agricultural crops (Austin et al. 1998, Wisdom and Cook 2000). Because crops are typically more digestible and contain higher levels of crude protein than do native grasses and browse species, they are often selected and

Received: 18 March 2013; Accepted: 10 September 2013

Published: 21 February 2014

${ }^{1}$ E-mail: heather.johnson@state.co.us

${ }^{2}$ Present address: United States Geological Survey, Pennsylvania Cooperative Fish and Wildlife Research Unit, 403 Forest Resources Building, University Park, PA 16802, USA

${ }^{3}$ Present address: Missouri Department of Conservation, $2901 \mathrm{~W}$

Truman Boulevard, Jefferson City, MO 65109, USA consumed by wild cervids (Mould and Robbins 1982). Agricultural producers have reported more damage by elk and deer (Odocoileus sp.) than any other wildlife species, and damage by deer alone has been projected to exceed US $\$ 100$ million annually in the United States (Conover 2002). Cervid damage to crops has created notable challenges for wildlife management agencies, because agencies are often responsible for both maintaining cervid population sizes while minimizing damage to agriculture (Wagner et al. 1997, Van Tassell et al. 1999, Hegel et al. 2009, Walter et al. 2010).

Agricultural producers often experience varying amounts of crop depredation caused by cervids depending on the seasonal distribution, abundance, and landscape configuration of local food resources (Vecellio et al. 1994, Yoder 2002, Hegel et al. 2009). For example, damage can be variable both within and among growing seasons, because 
local precipitation and temperatures will alter the availability of native forage and the motivation of deer and elk to feed on agricultural products (Walter et al. 2010). The proximity of cropland and wildland is also important in predicting patterns of damage, because cultivated fields closer to wildlife cover experience greater depredation (Nixon et al. 1991, Hegel et al. 2009). As a result, the effectiveness of management practices to reduce cervid damage may vary based on native forage availability, proximity of cover, and other habitat features (Hegel et al. 2009).

Common management tools used to reduce cervid damage to crops include permanent fencing and lethal removal of animals through depredation permits (Walter et al. 2010); however, there are drawbacks to each approach. Permanent cervid-proof fencing is effective but often cost-prohibitive for agricultural producers that have large tracts of land (VerCauteren et al. 2006) or grow crops on a rotational basis where only one crop type experiences high rates of damage. Permanent fencing is also a concern because it can interfere with wildlife movements and reduce access to nearby habitat. Wildlife agencies use depredation permits to lethally remove animals causing damage, but tolerance for these permits is often low among hunters, some producers, and the general public (Patricia D. Dorsey, Colorado Parks and Wildlife, unpublished data). Hunters often perceive depredation permits as reducing hunting opportunity (Fritzell et al. 1995, Horton and Craven 1997), particularly when local deer and elk population sizes are below agency management objectives. Depredation permits are also often unpopular with the public, particularly when lethal removal includes female cervids with dependent young.

Identifying cost-effective, non-lethal methods that reduce cervid damage to agricultural crops is of particular interest in Colorado, USA. Deer and elk account for about $50 \%$ of wildlife damage claims on agriculture, and Colorado Parks and Wildlife is mandated to pay all eligible claims. These compensation payments are costly (i.e., US $\$ 458,760$ was paid in compensation for deer and elk damage in 2012; Colorado Parks and Wildlife 2012); thus, Colorado Parks and Wildlife is interested in methods to reduce cervid depredation and associated payments. While damage to agriculture is a management concern, many of Colorado's deer and elk populations are at or below their management objectives, making depredation permits highly unpalatable to local hunters and the general public. Because deer and elk often depend upon private lands for habitat, finding costeffective, non-lethal solutions to prevent cervid depredation is also essential to encourage private landowner tolerance of wildlife and to build effective agency-landowner partnerships.

To identify cost-effective, non-lethal strategies for reducing deer and elk damage to crops, our objective was to experimentally test 3 temporary techniques: 1) a 5-strand polyrope electric fence (hereafter, electric), 2) an organic chemical repellent (Plantskydd ${ }^{\mathrm{TM}}$; hereafter, repellent), and 3) a winged or partial fence (hereafter, winged). These methods are less expensive than permanent fencing and can be implemented on a temporary basis to account for crop rotation (VerCauteren et al. 2006, Walter et al. 2010). Although these methods have received some testing on white- and black-tailed deer (Odocoileus virginianus, $O$. $h$. columbianus; Nolte 1998, Seamans and VerCauteren 2006, Hildreth et al. 2012), little is known about their effectiveness in reducing mule deer or elk damage to agriculture.

\section{STUDY AREA}

We tested temporary exclusion and repellent techniques for deer and elk near Dove Creek, Colorado, USA (Dolores County; $37^{\circ} 45^{\prime} 58.05^{\prime \prime} \mathrm{N}, 108^{\circ} 54^{\prime} 21.10^{\prime \prime} \mathrm{W}$; Fig. 1). Experimental plots were placed in agricultural fields growing sunflowers that were spatially juxtaposed to native vegetation and wildland canyons, and which had previously experienced cervid damage (Matthew Hammond, Colorado Parks and Wildlife, unpublished data). All sunflower fields were located on private property, but the region generally consisted of a mix of private and public lands.

Elevation in the study area ranged from 1,981-m to 2,590$\mathrm{m}$, and vegetation was characterized as mountain shrub and pinyon-juniper woodlands, interspersed with irrigated and dryland agriculture. The native vegetation was primarily composed of serviceberry (Amelanchier alnifolia), bitterbrush (Purshia tridentata), mountain mahogany (Cercocarpus montanus), wild crab apple (Peraphyllum ramosissimum), black sagebrush (Artemisia nova), pinyon pine (Pinus edulis),

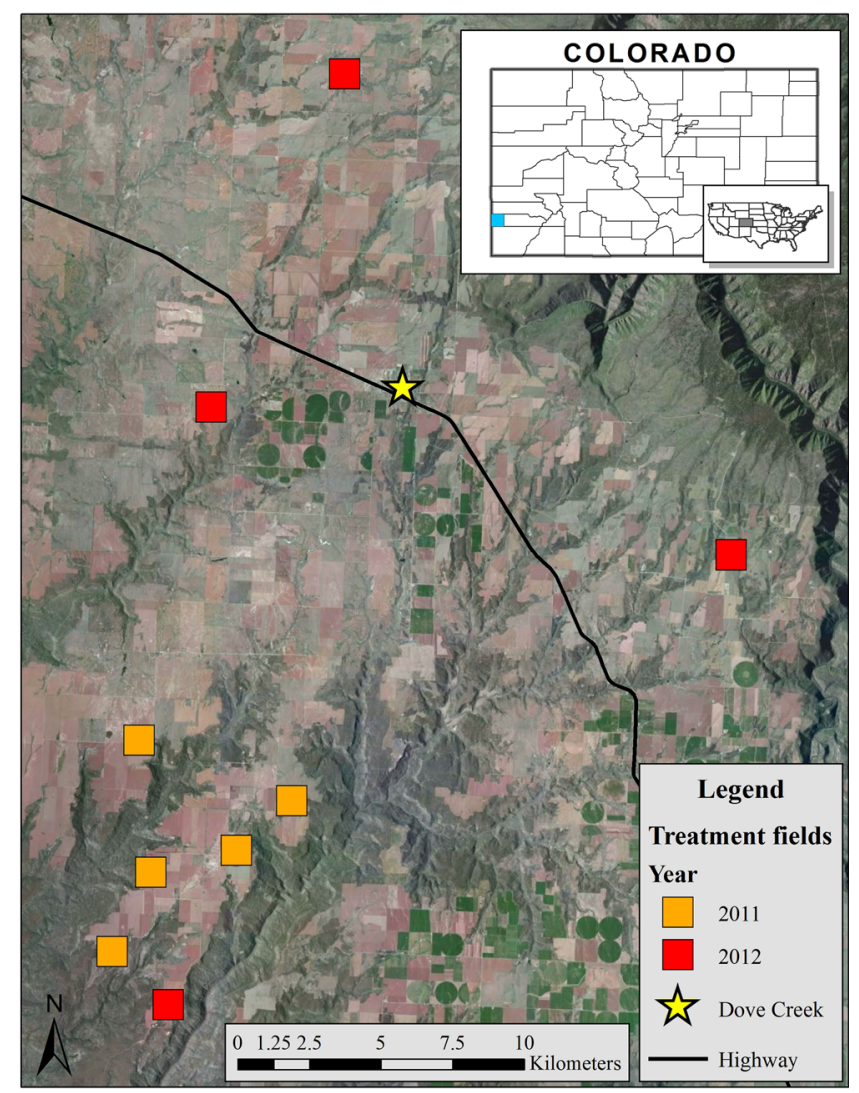

Figure 1. Location of experimental treatment fields near Dove Creek, Colorado, USA where exclusion and repellent methods for cervids were evaluated during July through October 2011 and 2012. 
and juniper (Juniperus osteosperma). Between 1996 and 2012, mean annual precipitation was $26.7-\mathrm{cm}$, which was typically received during late summer rains and as snow during winter (Weather Station DVCO1, Colorado Agricultural Meteorological Network 2012). Mean annual minimum and maximum temperatures were $-0.4^{\circ} \mathrm{C}$ and $16.6^{\circ} \mathrm{C}$, respectively (Colorado Agricultural Meteorological Network 2012). Since 1998, estimated deer population sizes have been consistently below Colorado Parks and Wildlife's management objectives, while the estimated elk population size has been above or within management objectives (A. Andrew Holland, Colorado Parks and Wildlife, unpublished data).

The study area has experienced high rates of mule deer and elk agricultural damage in association with a recent switch in the types of crops that are grown. Farmers traditionally grew dry beans, spring and winter wheat, and grass hay, which experienced minimal damage by cervids. Since 2007, however, many farmers started growing sunflowers on a rotational basis; this is a high-value seed oil crop used for biofuel, and farmers have experienced up to $100 \%$ depredation on fields in some years. Sunflowers in the region are generally grown on a 3- to 4-year rotation with other crops (e.g., winter wheat, pinto beans) that experience minimal damage, and thus producers were interested in exclusion or repellent techniques that could be moved between fields in different years. Cervid damage in this area was also exacerbated by the spatial juxtaposition of agricultural fields alongside wildland canyons that provided refugia for deer and elk (Fig. 1).

\section{METHODS}

\section{Exclusion and Repellent Methods Evaluated}

Electric.-We tested a polyrope electric fence (ElectroBraid $^{\mathrm{TM}}$ Fence Limited, Yarmouth, NS, Canada; approx. US $\$ 5-10 / \mathrm{m}$ for materials), which acts primarily as a psychological barrier based on learned behavioral and avoidance conditioning (Fig. 2A; McKillop and Sibly 1988, VerCauteren et al. 2012). The fence consisted of conductive copper wires woven into synthetic "ropes" that are more durable, visible, and easier to install than traditional electric fence designs (Hygnstrom and Craven 1988,
Seamans and VerCauteren 2006, VerCauteren et al. 2006, Fischer et al. 2011). We constructed fences $1.8-\mathrm{m}$ high, with wooden h-brace assemblies placed approximately every $100-\mathrm{m}$ and metal t-posts spaced every $15-\mathrm{m}$. Five polyrope lines were attached to the fence posts at 20,56,89,135, and $183-\mathrm{cm}$ above ground to discourage deer and elk incursions. Avoidance conditioning occurs when an animal contacts the fence, often with the nose or tongue, and receives an electric shock. Polyrope fences have reduced white-tailed deer damage to crops (Hygnstrom and Craven 1988, Seamans and VerCauteren 2006), but have not been experimentally tested for reducing mule deer or elk damage. The polyrope fence used a Speedrite ${ }^{\mathrm{TM}} 3000$ energizer (Tru-Test Incorporated, San Antonio, TX), which had a maximum pulse output of 3.0-J and was operated from a $12-\mathrm{V}$ deep-cycle battery with a solar-panel recharger.

Repellent.-We tested the effectiveness of Plantskydd ${ }^{\mathrm{TM}}$ (Tree World Plant Care Products, Inc., St. Joseph, MO) for reducing deer and elk damage. This repellent can be used on conventional and organic crops and can be applied by ground or aerial spraying. Plantskydd ${ }^{\mathrm{TM}}$ was developed in Sweden for reducing mammalian wildlife damage on commercial forests. The active ingredient is dried bloodmeal, which the manufacturer asserts works by emitting an odor that wildlife associate with predator presence. We mixed Plantskydd ${ }^{\mathrm{TM}}$ powder with water following the manufacturer's directions for severe damage $\left(14.8-\mathrm{kg}\right.$ of Plantskydd ${ }^{\mathrm{TM}} /$ plot perimeter). The manufacturer recommends spraying a swath $\geq 10-\mathrm{m}$ around plot perimeters, and we sprayed an $18-\mathrm{m}$ swath around treatment plot perimeters, the maximum distance that could be covered with our industrial ground sprayer (Model 4720; John Deere, Deere and Company, Moline, IL). Given materials and application, this treatment cost $\leq \mathrm{US} \$ 1 / \mathrm{m}$ of field perimeter spraying. We applied Plantskydd ${ }^{\mathrm{TM}}$ monthly throughout the growing season (Jul-Sep) to account for the repellent washing off or degrading, and to spray new plant growth. Plantskydd ${ }^{\mathrm{TM}}$ has reduced damage to tree seedlings caused by black-tailed deer (Nolte 1998, Wagner and Nolte 2001), but has been not been tested on mule deer or elk.

Winged fence.-Hildreth et al. (2012) recently experimented with "winged" or "partial" fences designed to reduce white-tailed deer access along field edges adjacent to cover.
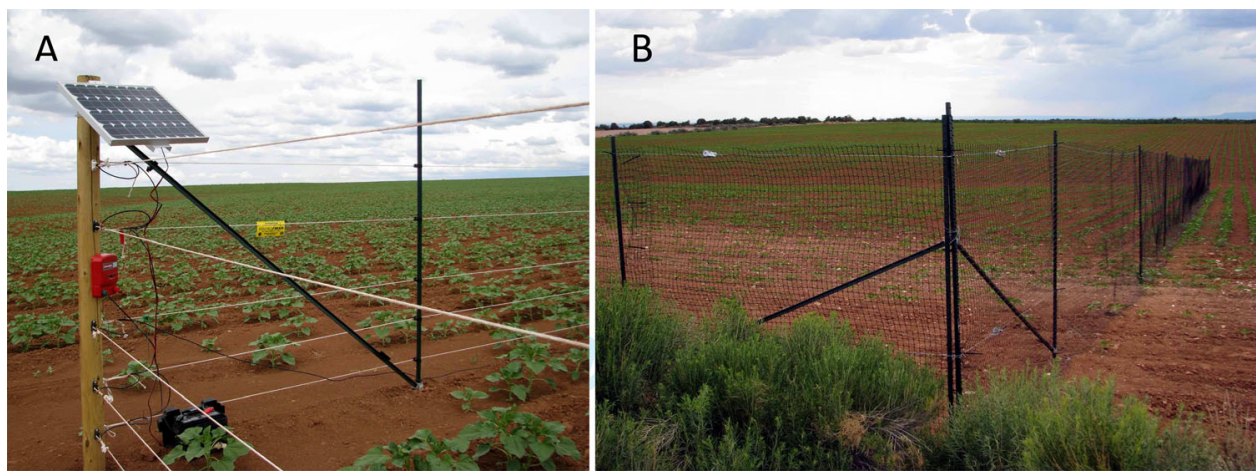

Figure 2. A polyrope electric fence (A) and a partial winged fence (B) for excluding deer and elk from agricultural fields. 
The fence is completely installed on the field side that borders native vegetation, and partially installed on the perpendicular sides, creating "wings" that extend around a portion of the field (Fig. 2B; approx. US $\$ 6 / \mathrm{m}$ for materials). This fence is highly economical because only a portion of the field must be enclosed and materials can be easily erected and removed depending on crop rotation. We installed winged fences following Hildreth et al. (2012), where the side of the treatment plot closest to the crop-wildland interface received complete protection. We erected fences $2.1-\mathrm{m}$ in height, which consisted of ultraviolet-stable polypropylene highstrength mesh (Benner's Gardens, Phoenixville, PA) secured to 3-m metal t-posts spaced every 7-m using cable ties. Two strands of 12.5 -gauge high-tensile wire were placed $0.8-\mathrm{m}$ and $2.1-\mathrm{m}$ above ground, so the mesh could be suspended and anchored to the wire with circular staples along the length of the fence for support. The fence also had a $0.2-\mathrm{m}$ apron extending outward from the field, secured with $0.3-\mathrm{m}$ steel stakes, to further reduce elk and deer access. Corners and ends of the winged fence were supported with metal $\mathrm{t}$-post angled $\mathrm{h}$-brace assemblies. The fence wings extended $50-\mathrm{m}$ along the 2 sides of the treatment plots that were adjacent to the fully installed side of the fence.

\section{Experimental Design}

We used a randomized block design (Gotelli and Ellison 2004) where each "block" was a sunflower field (approx. 6580 ha in size) that had previously experienced cervid crop damage, and which was directly adjacent to the wildland boundary where damage was expected to be greatest (Fig. 1). Within each field, we delineated four 4 ha treatment plots. Treatment plots were randomly assigned to receive one of the following treatments: no exclusion or repellent method (control), electric fence, repellent, or winged fence. We used this design to account for environmental heterogeneity, because we expected damage to vary among fields. We monitored 5 replicate fields during 2011 (Fields A-E) and 4 replicate fields in 2012 (Fields F-I); because sunflowers were grown on rotation the same fields were not tested in both years. Fences were constructed in late June and early July after sunflowers had germinated to ensure planting was successful, as pests or low soil moisture can cause failure in germination. The corners of all plots were marked with easily visible metal stakes to facilitate data collection.

\section{Monitoring Fence Effectiveness}

We monitored plots in each field for 2 response variables: damage to sunflower plants and number of deer and elk tracks traversing plot boundaries (entry or exit into plots). We used the variable-area-transect method for estimation of crop damage (Engeman and Sugihara 1998; Engeman and Sterner 2002; Gilsdorf et al. 2004a, b), conducting final damage assessments immediately before harvest (mid-Oct). In 2011, we assessed damage on 15 transects/plot, and in 2012 we increased the number to 30 transects/plot. For each transect, we randomly (and with replacement) identified a starting location within the plot and inspected a row of sunflowers, counting the total number of sunflower plants, and the number of plants that were damaged by deer or elk.
Typical damage was characterized by the removal of the terminal bud, consumption of the seed head, and trampling of the plants, as verified by accompanying cervid tracks. If 5 cervid-damaged sunflowers were tallied within $100-\mathrm{m}$, we recorded the distance traveled to the fifth damaged plant $(<100-\mathrm{m})$ and the total number of sunflower plants observed within that distance. If 5 cervid-damaged sunflowers were not tallied within $100-\mathrm{m}$, the observer recorded the total number of sunflowers and the number of cervid-damaged plants counted within that distance. If the end of the sunflower row was reached before completing a transect, the observer would randomly select an adjacent row (i.e., right or left row) for completing the transect.

We also monitored each treatment and control plot for deer and elk tracks that traversed plot boundaries on a bimonthly basis throughout the growing season (mid-Jul through midOct). An observer would walk the perimeter of each plot, counting the total number of deer and elk tracks that crossed the plot perimeter. Cervid tracks were raked or stamped out after each observation to avoid double-counting in subsequent sampling periods.

\section{Statistical Approach}

We calculated mean proportion of end-of-season damage for each treatment and control plot, and mean number of elk and deer tracks traversing plot perimeters for each plot across the growing season. We also calculated mean values separately for fields monitored in 2011 and 2012, as cervid damage was uncharacteristically low in 2011. We did not include end-ofseason damage values from the repellent plot of one field (Field F in 2012) because cervid damage occurred in that plot before the first application of the repellent. Similarly, end-ofseason damage information from all treatment plots of a field in 2012 (Field I) were removed from data summaries and analyses because substantial depredation occurred after germination but before fence construction.

We used a generalized linear mixed model to identify whether exclusion or repellent treatment types were effective in reducing cervid damage to sunflower plots (Pinheiro and Bates 2000). Because damage data were recorded for each transect as the number of damaged plants/total plants, we used a binomial distribution with a logit link function (Bolker et al. 2009). Treatment was included in the model as a categorical fixed effect (control plots were considered the reference class) and we nested plot within field within year for the random-effects model structure. We used model coefficients to assess the direction and magnitude of different treatment types on cervid damage (95\% CIs non-overlapping zero).

To evaluate the influence of exclusion or repellent types on deer and elk tracks traversing plot perimeters, we used generalized linear mixed models with Poisson distributions and $\log$ link functions. As with the damage models, we included treatment type as a categorical fixed effect and nested plot within field within year for the random effects portion of the model. We generated separate models for predicting the number of tracks by deer and elk, because we hypothesized that treatments may vary in their effectiveness 
among cervid species (e.g., VerCauteren et al. 2006, Walter et al. 2010). As with the damage model, we used model coefficients, and their $95 \%$ confidence intervals, to assess the direction and magnitude of treatment effects on the number of tracks traversing plot boundaries. We used the package "lme4" in Program R for all statistical modeling (R Core Team 2012).

\section{RESULTS}

Cervid damage and tracks varied across treatment and control plots. Just prior to harvest, the percentage of sunflowers damaged by cervids across plots and years ranged from $0.0 \%$ to $72.6 \%(\bar{x}=8.3, \mathrm{SE}=0.8)$. The mean bimonthly number of deer tracks crossing plot perimeters ranged from 0 to $149.8(\bar{x}=23.0, \mathrm{SE}=5.3)$ and the mean number of elk tracks ranged from 0 to $21.6(\bar{x}=5.3$, $\mathrm{SE}=1.1)$. Mean percentage sunflower damage and number of deer tracks were greater in 2012 than in 2011 (damage: $t=-3.300, \mathrm{df}=29, P=0.003 \quad$ [Fig. 3A]; deer tracks: $t=-4.512, \mathrm{df}=34, P<0.001$; Fig. $3 \mathrm{~B})$, but mean values

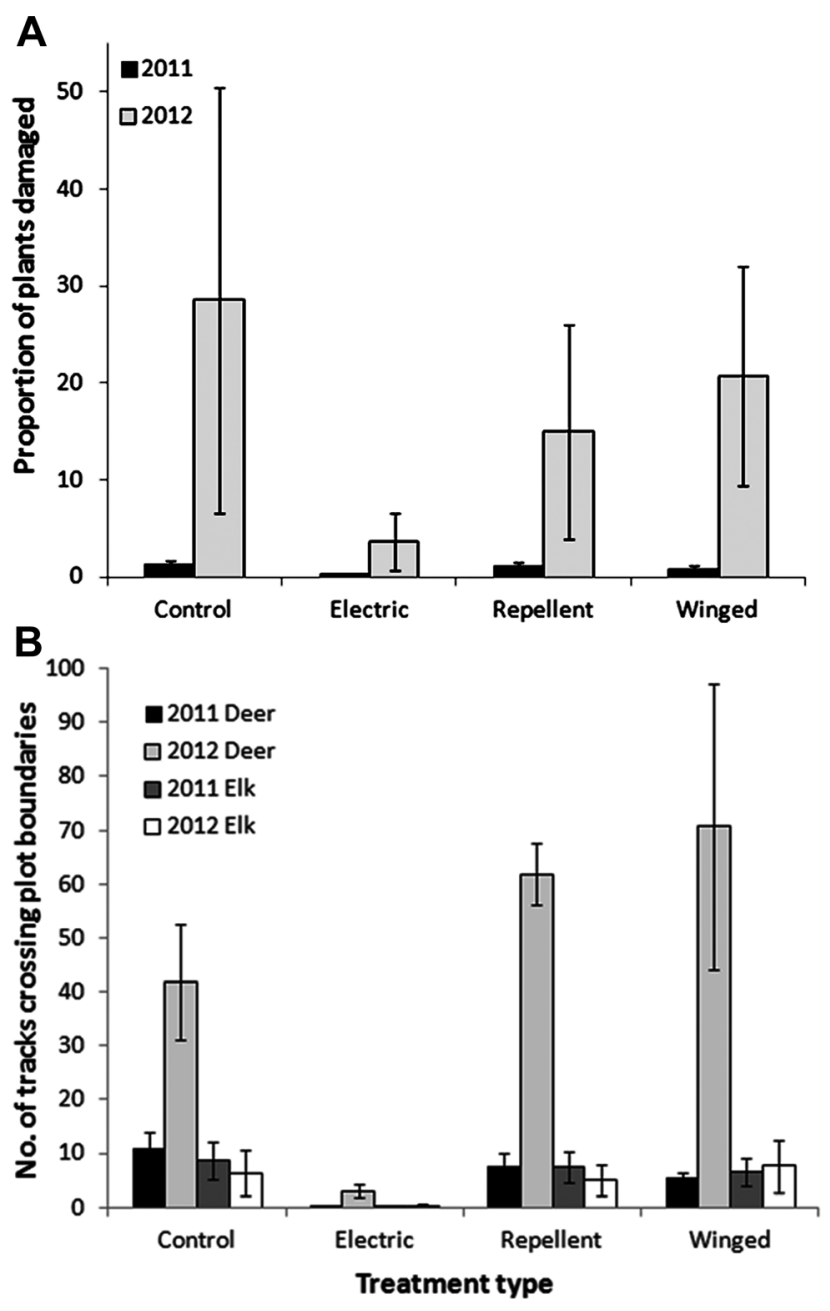

Figure 3. Proportion of sunflower plants damaged at time of harvest (A) and number of deer and elk tracks that crossed plot boundaries (B), summarized across plots ( $\bar{x}$ and SE) for each treatment type, Dove Creek, Colorado, USA, 2011 and 2012. for elk tracks were similar between years $(t=0.371, \mathrm{df}=34$, $P=0.713)$. In 2011, treatment and control plots averaged $0.9 \%$ sunflower plant damage at the end of the growing season, and a bimonthly average of 6.0 deer and 5.7 elk tracks crossed plot boundaries. Conversely, 2012 plots had an average of $17.1 \%$ of plants damaged at harvest and an average of 44.4 deer tracks and 4.9 elk tracks crossed plot boundaries on a bimonthly basis. Despite differences in damage between years, plots protected with electric fencing consistently received the least amount of cervid damage and tracks (Fig. 3).

The only treatment type that reduced damage to sunflowers was the electric fence (Table 1). Treatment effects on damage across both years, however, showed limited biological effect given that more data were collected in 2011 when minimal damage occurred. Across years, the mean proportion of damaged plants on electric fence plots was 0.01 (95\% $\mathrm{CI}=0.00-0.03)$, on control plots was $0.05(95 \% \mathrm{CI}=0.00$ $0.33)$, on repellent fences was $0.04(95 \% \mathrm{CI}=0.01-0.15)$, and on winged fences was $0.04(95 \% \mathrm{CI}=0.01-0.15)$.

Electric fencing was also the only treatment type that reduced cervid activity within sunflower plots (Table 1). The average bimonthly number of deer tracks that crossed plot perimeters on plots with electric fencing was 0.6 (95\% $\mathrm{CI}=0.3-1.1)$, on control plots was $18.5(95 \% \mathrm{CI}=3.8$ 91.5), on repellent fence plots was $18.4(95 \% \mathrm{CI}=11.4$ 29.7), and on winged plots was 16.8 (95\% CI $=10.4-27.0)$. Electric fences also reduced the number of elk that crossed plot perimeters on a bimonthly basis, but the effect was less than for deer. An average of only 0.1 elk tracks crossed electric-fence plot boundaries $(95 \% \mathrm{CI}=0.0-0.2)$, while 4.3 crossed control plots $(95 \% \mathrm{CI}=1.8-10.3), 3.4$ crossed repellent plots ( $95 \% \mathrm{CI}=2.2-5.2)$, and 3.7 crossed winged plots $(95 \% \mathrm{CI}=2.4-5.7)$.

\section{DISCUSSION}

As wildlife management agencies look for methods to reduce cervid damage to agricultural crops while maintaining deer and elk population sizes, non-lethal methods of crop protection will become increasingly important. We tested 3 methods for reducing deer and elk damage to sunflowers, a high-value crop, but found that only polyrope electric fencing significantly reduced damage and use by deer and elk. Investigators have found different polyrope electric fence designs to be successful at reducing white-tailed deer damage to crops (Hygnstrom and Craven 1988, Seamans and VerCauteren 2006), but to our knowledge, this is the first study to test the 5-strand polyrope fence design on mule deer or elk. Polyrope appears to be effective at reducing deer and elk damage to sunflowers, providing a temporary and costeffective option for producers to reduce depredation through non-lethal means.

Although the chemical repellent Plantskydd ${ }^{\mathrm{TM}}$ is advertised to imitate predator presence and induce fear in cervids, it was not consistently effective in our evaluation. Fearinducing repellents are generally more successful than repellents with other strategies (i.e., aversive taste or paininducing; Wagner and Nolte 2001), and studies have found 
Table 1. Coefficients for fixed effects from generalized linear mixed models evaluating the effectiveness of different treatment types for reducing cervid sunflower damage and the number of deer and elk tracks traversing experimental plot boundaries, from research conducted near Dove Creek, Colorado, USA, 2011 and 2012.

\begin{tabular}{|c|c|c|c|c|c|c|}
\hline Model & Variable & $\boldsymbol{\beta}$ & SE & $P$ & L 95\% CI & U 95\% CI \\
\hline \multirow[t]{5}{*}{ Damage } & Intercept $^{\mathrm{a}}$ & -3.020 & 1.169 & $<0.010$ & -5.311 & -0.729 \\
\hline & Treatment & & & & & \\
\hline & Electric $^{a}$ & -2.227 & 0.943 & 0.018 & -4.075 & -0.379 \\
\hline & Repellent & -0.296 & 0.806 & 0.713 & -1.876 & 1.284 \\
\hline & Winged & -0.108 & 0.709 & 0.879 & -1.498 & 1.282 \\
\hline \multirow[t]{5}{*}{ Deer tracks } & Intercept $^{\mathrm{a}}$ & 2.919 & 0.815 & $<0.001$ & 1.322 & 4.516 \\
\hline & Treatment & & & & & \\
\hline & Electric $^{\mathrm{a}}$ & -3.451 & 0.302 & $<0.001$ & -4.043 & -2.859 \\
\hline & Repellent & -0.005 & 0.244 & 0.982 & -0.483 & 0.473 \\
\hline & Winged & -0.100 & 0.244 & 0.684 & -0.578 & 0.378 \\
\hline \multirow[t]{5}{*}{ Elk tracks } & Intercept $^{\mathrm{a}}$ & 1.468 & 0.441 & $<0.001$ & 0.604 & 2.332 \\
\hline & Treatment & & & & & \\
\hline & Electric $^{\mathrm{a}}$ & -4.052 & 0.416 & $<0.001$ & -4.867 & -3.237 \\
\hline & Repellent & -0.249 & 0.222 & 0.262 & -0.684 & 0.186 \\
\hline & Winged & -0.163 & 0.221 & 0.460 & -0.596 & 0.270 \\
\hline
\end{tabular}

${ }^{a}$ Statistically significant at $\alpha=0.05$ level.

this repellent to reduce black-tailed deer damage to tree seedlings (Nolte 1998, Wagner and Nolte 2001). In our sunflower plots, however, the repellent did not reduce mule deer or elk damage or tracks, a result that may be influenced by numerous factors, including animal habituation, availability of native forage, local weather conditions, animal nutritional state, repellent concentration, or the frequency of repellant application (Kimball et al. 2009, Walter et al. 2010, Elmeros et al. 2011). Indeed, drought conditions in 2012 may have increased motivation by deer and elk to forage on sunflowers, despite the repellent odor. We applied repellent once per month to treatment plots. Although $>1$ application/month may have increased the effectiveness of the treatment, such a high frequency of applications would not be feasible for most sunflower producers, and therefore, not particularly useful as a routine damage management tool.

The winged fence we used also did not decrease deer and elk damage and use of the plots. In contrast, Hildreth et al. (2012) found winged fencing reduced white-tailed deer depredation to corn by $13.5 \%$. Based on profits from the yield of corn and the cost of fence construction, Hildreth et al. (2012) concluded that corn producers could save approximately US $\$ 205 /$ ha annually by using a winged fence along the agriculture-wildland interface. In our experiment, damage in winged plots was less than control plots in 7 of 8 fields, but did not have a strong treatment effect. We often observed elk and deer tracks along the partial portion of the fence to cross into the plot at the termination of the wing. DeVault et al. (2008) reported similar results in which whitetailed deer traveled around partial fences at an airport runway to gain access to crop fields. Animal habituation and motivation, crop palatability, and fence wing length may all influence the success of this approach. We placed the fully fenced treatment side against the dominant wildland boundary, but the complex juxtaposition of agricultural fields and canyons in southwestern Colorado may reduce the utility of this approach in this region. This exclusionary method may perform better in a more homogenous landscape.
Given that the number of elk tracks remained fairly consistent between years, while the number of deer tracks was greater in 2012, it appears that the greater damage rates in 2012 were primarily attributable to deer crop depredation. Elk in the vicinity of Dove Creek migrate seasonally, often arriving at agricultural areas during summer, and spending the remainder of the year in secluded, wildland canyons (Matthew Hammond, unpublished data). In contrast, mule deer often inhabit agricultural areas year-round (Matthew Hammond, unpublished data), potentially increasing their habituation to novel structures and odors. In the case of electric fencing, smaller bodied deer are more likely able to breach the strands of polyrope, an obstacle which may be more effective at inhibiting larger bodied elk. Despite differences in habitat-use patterns, behavior, and morphology of deer and elk, polyrope electric fences were effective at reducing crop damage for both species.

We tested 3 techniques for reducing damage to sunflowers during 2011 and 2012, years when crop depredation was dramatically variable. In 2011, deer and elk damage to sunflowers averaged 1\%, well within tolerance levels for farmers as evidenced by no damage claims filed by farmers that year (Matthew Hammond, unpublished data). Spring and summer (Mar-Aug) precipitation was exceedingly high during 2011 (Weather Station DVCO1, Colorado Agricultural Meteorological Network 2012; approx. 153\% of normal), and it appears that the availability of abundant natural forage likely reduced damage by deer and elk. In 2012, however, the Dove Creek region experienced a drought, receiving about $60 \%$ of spring and summer precipitation, and only $30 \%$ of average spring (Mar-Jun) rainfall, a critical time for dryland farming in southwest Colorado. Soil moisture was so low in 2012 that few producers planted sunflowers, and the majority of seeds planted in some fields never germinated. We suspect that observed differences in plot damage and use between 2011 and 2012 were largely driven by differences in weather and the resulting effects on the native vegetation for deer and elk. 
High temporal and spatial variability in cervid damage, as observed in this study, is particularly challenging for producers and wildlife management agencies seeking solutions to reduce depredation. Such variability may reduce the motivation of producers to protect crops and alter priorities of wildlife managers, depending on whether cervid damage is severe or minimal in a particular year or area. This variability in damage also highlights the utility of a temporary method, such as polyrope electric fence, for protecting crops when damage is expected to be high (e.g., in drought years). Ultimately, however, the decision to invest in a tool such as polyrope electric fencing will depend on field size, expected amount of damage, crop prices, and the frequency and duration a producer will need to use the fencing, particularly for rotational crops.

\section{MANAGEMENT IMPLICATIONS}

For wildlife agencies seeking non-lethal management options for reducing deer and elk damage to high-value agricultural crops, we found that 5-strand polyrope electric fencing was effective. Polyrope is easy to assemble and disassemble, cost-effective relative to permanent fencing, and can be used on a temporary basis to minimize damage for certain crops grown on rotation or during years when natural forage for cervids is scarce. In areas where management agencies are working to maintain or increase deer and elk populations, but reduce cervid damage, the application of an effective exclusion technique such as polyrope electric fencing could protect high-value crops, decrease the need for compensation payments and lethal cervid depredation permits, and increase satisfaction of producers and the public. Wildlife agencies will need to continue to work with producers to test and apply management techniques for crop protection based on the wildlife species present, population densities, crop types, landscape configuration, and abundance of local forage.

\section{ACKNOWLEDGMENTS}

We thank M. Glow, C. Priest, M. Preisler, A. Brown, A. Hildreth, M. Lavelle, G. Martin, D. Sanders, and B. Beltran-Beck for collecting field data and helping with fence construction. We also thank T. Brown and G. Phillips for help in purchasing fencing supplies; and A. Berrada, P. White and D. Fernandez for project support. This project would not have been possible without the cooperation of landowners around Dove Creek. Funding was provided by the U.S. Department of Agriculture National Wildlife Research Center, Colorado Habitat Partnership Program, Montelores Habitat Partnership Program, Rocky Mountain Elk Foundation, and Colorado Parks and Wildlife AuctionRaffle Grant program.

\section{LITERATURE CITED}

Austin, D. D., P. J. Urness, and D. Duersch. 1998. Alfalfa hay crop loss due to mule deer depredation. Journal of Range Management 51:29-31.

Bolker, B. M., M. E. Brooks, C. J. Clark, S. W. Geange, J. R. Poulsen, M. H. H. Stevens, and J.-S. S. White. 2009. Generalized linear mixed models: a practical guide for ecology and evolution. Trends in Ecology and Evolution 24:127-135.

Colorado Agricultural Meteorological Network. 2012. COAgMet homepage. http://ccc.atmos.colostate.edu/ coagmet/index.php. Accessed 10 Jan 2013.

Colorado Parks and Wildlife. 2012. FY12 game damage claims annual report. Colorado Parks and Wildlife, Denver, USA.

Conover, M. R. 2002. Resolving human-wildlife conflicts: the science of wildlife damage management. CRC Press, Boca Raton, Florida, USA.

DeVault, T. L., J. E. Kubel, D. J. Glista, and O. E. Rhodes. 2008. Mammalian hazards at small airports in Indiana: impact of perimeter fencing. Human-Wildlife Conflicts 2:240-247.

Elmeros, M., J. K. Winbladh, P. N. Andersen, A. B. Madsen, and J. T. Christensen. 2011. Effectiveness of odour repellents on red deer (Cervus elaphus) and roe deer (Capreolus capreolus): a field test. European Journal of Wildlife Research 57:1223-1226.

Engeman, R. M., and R. T. Sterner. 2002. A comparison of potential laborsaving sampling methods for assessing large mammal damage in corn. Crop Protection 21:101-105.

Engeman, R. M., and R. T. Sugihara. 1998. Optimization of variable area transect sampling using Monte Carlo simulation. Ecology 79:14251434.

Fischer, J. W., G. E. Philips, D. M. Baasch, M. J. Lavelle, and K. C. VerCauteren. 2011. Modifying elk (Cervus elaphus) behavior with electric fencing at established fence-lines to reduce disease transmission potential. Wildlife Society Bulletin 35:9-14.

Fritzell, P. A. Jr., D. L. Minnus, and R. B. Peyton. 1995. A comparison of deer hunter and farmer attitudes about crop damage abatement in Michigan: messages for hunters, farmers and managers. Seventh Eastern Wildlife Damage Management Conference, DigitalCommons@University of Nebraska, Lincoln, Nebraska, Paper 12.

Gilsdorf, J. M., S. E. Hygnstrom, K. C. VerCauteren, G. M. Clements, E. E. Blankenship, and R. M. Engeman. 2004a. Evaluation of a deeractivated bio-acoustic frightening device for reducing deer damage in cornfields. Wildlife Society Bulletin 32:515-523.

Gilsdorf, J. M., S. E. Hygnstrom, K. C. VerCauteren, G. M. Clements, E. E. Blankenship, and R. M. Engeman. 2004b. Propane exploders and Electronic Guards were ineffective at reducing deer damage in cornfields. Wildlife Society Bulletin 32:524-531.

Gotelli, N. J., and A. M. Ellison. 2004. A primer of ecological statistics. Sinauer, Sunderland, Massachusetts, USA.

Hegel, T. M., C. C. Gates, and D. Eslinger. 2009. The geography of conflict between elk and agricultural values in the Cypress Hills, Canada. Journal of Environmental Management 90:222-235.

Hildreth, A. M., S. E. Hygnstrom, E. E. Blankenship, and K. C. VerCauteren. 2012. Use of partially fenced fields to reduce deer damage to corn. Wildlife Society Bulletin 36:199-203.

Horton, R. R., and S. R. Craven. 1997. Perceptions of shooting-permit use for deer damage abatement in Wisconsin. Wildlife Society Bulletin 25:330-336.

Hygnstrom, S. E., and S. R. Craven. 1988. Electric fences and commercial repellents for reducing deer damage in cornfields. Wildlife Society Bulletin 16:291-296.

Kimball, B. A., J. Taylor, K. R. Perry, and C. Capelli. 2009. Deer responses to repellent stimuli. Journal of Chemical Ecology 35:1461-1470.

McKillop, I. G., and R. M. Sibly. 1988. Animal behaviour at electric fences and implications for management. Mammal Review 18:91-103.

Mould, E. D., and C. T. Robbins. 1982. Digestive capabilities in elk compared to white-tailed deer. Journal of Wildlife Management 46:2229.

Nixon, C. M., L. P. Hansen, P. A. Brewer, and J. E. Chelsvig. 1991. Ecology of white-tailed deer in an intensively farmed region of Illinois. Wildlife Monographs 118.

Nolte, D. L. 1998. Efficacy of selected repellents to deter deer browsing on conifer seedlings. International Biodeterioration and Biodegradation 42:101-107.

Pinheiro, J., and D. M. Bates. 2000. Mixed effects models in S and S-Plus. Springer-Verlag, New York, New York, USA.

$\mathrm{R}$ Core Team. 2012. R: a language and environment for statistical computing. Vienna, Austria, R Foundation for Statistical Computing. ISBN 3-900051-07-0, Version R 2.15.2, URL http://www.R-project.org/ 
Seamans, T. W., and K. C. VerCauteren. 2006. Evaluation of Electrobraid $^{\mathrm{TM}}$ fencing as a white-tailed deer barrier. Wildlife Society Bulletin 34:8-15.

Van Tassell, L. W., C. Phillips, and B. Yang. 1999. Depredation claim settlements in Wyoming. Wildlife Society Bulletin 25:886-894.

Vecellio, G. M., R. H. Yahner, and G. L. Storm. 1994. Crop damage by deer at Gettysburg Park. Wildlife Society Bulletin 22:89-93.

VerCauteren, K. C., R. Dolbeer, and E. Gese. 2012. Identification and management of wildlife damage. Pages 232-269 in N. Silvy, editor. The wildlife techniques manual. Seventh edition. The John Hopkins University Press, Baltimore, Maryland, USA.

VerCauteren, K. C., M. J. Lavelle, and S. E. Hygnstrom. 2006. Fences and deer-damage management: a review of designs and efficacy. Wildlife Society Bulletin 34:191-200.

Wagner, K. K., and D. L. Nolte. 2001. Comparison of active ingredients and delivery systems in deer repellents. Wildlife Society Bulletin 29:322-330.
Wagner, K. K., R. H. Schmidt, and M. R. Conover. 1997. Compensation programs for wildlife damage in North America. Wildlife Society Bulletin 25:312-319.

Walter, W. D., M. J. Lavelle, J. W. Fischer, T. L. Johnson, S. E. Hygnstrom, and K. C. VerCauteren. 2010. Management of damage by elk (Cervus elaphus) in North America: a review. Wildlife Research 37:630-646.

Wisdom, M. J., and J. G. Cook. 2000. North American elk. Pages 694-735 in S. Demarais, and P. R. Krausman, editors. Ecology and management of large mammals in North America. Prentice Hall, Upper Saddle River, New Jersey, USA.

Yoder, J. 2002. Deer-inflicted crop damage and crop choice in Wisconsin. Human Dimensions of Wildlife 7:179-196.

Associate Editor: Belant. 